\title{
GERMINATION OF RYE BROME (Bromus secalinus L.) SEEDS UNDER SIMULATED DROUGHT AND DIFFERENT THERMAL CONDITIONS
}

\author{
${ }^{1}$ Małgorzata Haliniarz, ${ }^{1}$ Jan Kapeluszny, ${ }^{2}$ Sławomir Michałek \\ ${ }^{1}$ University of Life Sciences in Lublin, Department of Herbology and Plant Cultivation Techniques \\ 20-950 Lublin, Akademicka13, Poland \\ e-mail: malgorzata.haliniarz@up.lublin.pl \\ ${ }^{2}$ University of Life Sciences in Lublin, Department of Plant Physiology \\ 20-950 Lublin, Akademicka 15, Poland
}

Received: 02.03.2013

Abstract

The aim of the present study was to compare the germination of rye brome (Bromus secalinus L.) seeds and the initial growth of seedlings under simulated drought and different thermal conditions.

The study included two experiments carried out under laboratory conditions in the spring of 2012. The first experiment involved an evaluation of the speed of germination as well as of the biometric characters and weight of seedlings in polyethylene glycol solutions (PEG 8000) in which the water potential was: $-0.2 ;-0.4 ;-0.65 ;-0.9 \mathrm{MPa}$, and in distilled water as the control treatment. The experiment was conducted at the following temperatures: $25 / 22^{\circ} \mathrm{C}$ and $18 / 14^{\circ} \mathrm{C}$ day/night, at a relative air humidity of $90 \%$. The other experiment, in which lessive soil was used as a germination substrate, was carried out in a plant growth chamber at two levels of air humidity (55-65\% and $85-95 \%)$ and temperature $\left(22 / 10^{\circ} \mathrm{C}\right.$ and $\left.16 / 5^{\circ} \mathrm{C}\right)$. The soil moisture content was determined by the gravimetric method and the water potential corresponding to it was as follows: -0.02 , $-0.07,-0.16,-0.49,-1.55 \mathrm{MPa}$.

The germination capacity and emergence of Bromus secalinus as well as the weight of sprouts produced were significantly dependent on the water potential of the polyethylene glycol solution and on the soil water potential. The emergence of Bromus secalinus was completely inhibited by reducing the soil water potential below $-0.16 \mathrm{MPa}$ (the point of strong growth inhibition). The emergence and biometric characters of rye brome seedlings were significantly dependent on temperature and air humidity.

Key words: Bromus secalinus, germination, emergence, substrate water potential, thermal conditions
INTRODUCTION

Rye brome (Bromus secalinus L.) is an archaeophyte native to the Mediterranean area and it is considered to be a weed of mainly winter cereals. In the past, it was a common weed found across Polish lowlands and foothills. However, a constant regression of this species was observed in the 1970's. With the passage of time, it was listed as a threatened species [1-3].

Nevertheless, a much more frequent occurrence of rye brome in crop fields has been observed in recent years. Over the period 1971-1988, only 3 locations of this species were found in 169 winter cereal fields of the Sepopol Plain, whereas during the period 20072010 a survey of 215 fields in this region revealed 151 sites of occurrence of this species. In the Suwałki Landscape Park, the percentage of fields with the presence of Bromus secalinus also increased by $44.5 \%$ relative to the period 1971-1988 [4]. A more frequent occurrence of rye brome has also been found in other regions of Poland, such as Lublin Voivodeship [5], the Podlasie Bug River Gorge [6,7], and the Kałuszyn Upland [8].

Within the area of the Krzczonów Landscape Park (Lublin Upland), where this study was conducted, the intensity of occurrence of rye brome in winter cereal crops varied between years. An assumption was made that this was attributable to different soil moisture conditions during the period of sowing and emergence of winter cereals. Therefore, a research hypothesis was formulated that the soil moisture content determines the dormancy or germination of rye brome seeds. To verify 
this hypothesis, the germination of seeds and the initial growth of sprouts were investigated under simulated drought conditions using two methods and under different thermal conditions.

\section{MATERIALS AND METHODS}

This study included two experiments carried out under laboratory conditions in the spring of 2012.

The first experiment involved an evaluation of the germination dynamics and rate of growth of rye brome seedlings in aqueous polyethylene glycol solutions (PEG 8000), in which the water potential was as follows: $-0.2 ;-0.4 ;-0.65 ;-0.9 \mathrm{MPa}$, and in distilled water as the control treatment. The experiment was conducted in glass dishes on filter paper at the following temperatures: $25 / 22^{\circ} \mathrm{C}$ and $18 / 14^{\circ} \mathrm{C}$ day/night, at a relative air humidity of $90 \%$ which was maintained throughout the duration of the experiment. Seeds that produced a radicle (germination) and those that produced a radicle and a coleoptile (emergence) were counted every day over a period of 10 days. Moreover, based on daily monitoring of the controlled germination and emergence, their speed indices were calculated according to Maguire [9] using the following formula: number of seeds germinated/first day of counting +.....+ number of seeds germinated/last day of counting. On the tenth day of the experiment, the length of the longest radicle and leaf was measured in $\mathrm{mm}$ as well as the above-ground fresh weight per plant was determined in $\mathrm{mg}$.

The other experiment was carried out in plastic containers with lessive soil originating from the Czesławice Experimental Farm. The soil moisture content was determined by the gravimetric method and the water potential corresponding to it was as follows: $-0.02,-0.07,-0.16,-0.49,-1.55 \mathrm{MPa}$. The soil moisture levels, which were experimental treatments, were accepted based on the results of tests of the soil from the Czesławice Experimental Farm made by SłowińskaJurkiewicz [10]. The experiment was carried out in a plant growth chamber at two levels of air humidity (55-65\% and $85-95 \%)$ and temperature $\left(22 / 10^{\circ} \mathrm{C}\right.$ and $\left.16 / 5^{\circ} \mathrm{C}\right)$. Rye brome sprouts were counted each day, while after 14 days the length of the longest radicle and leaf was measured as well as the air-dry weight of the underground and above-ground parts of seedlings was determined. The weight values were calculated per plant.

Seeds collected in Czesławice in 2010 from a winter wheat crop were used in both experiments. 100 mature seeds were sown in each container and dish. The experiment was conducted in triplicate. The obtained results of both experiments were statistically analysed by analysis of variance and the means were compared by Tukey's test at a significance level of $\mathrm{p}=0.05$. Before starting statistical calculations, the percentage values were transformed according to the formula $y=\arcsin \sqrt{x}$.

\section{RESULTS}

In the experiments that used different aqueous polyethylene glycol solutions (PEG 8000), the germination dynamics, the seed germination capacity as well as the speed of germination and emergence, as determined by Maguire's index, were significantly dependent on the substrate water potential (Tables 1,2,3; Fig. 1). Rye brome found the most favourable conditions for germination and initial growth in dishes with distilled water as the control treatment. Under these conditions, its germination capacity was $97.4 \%$ and seeds were characterized by high germination and emergence speed indices, which were 56.1 and 25.2, respectively. Deterioration in water conditions significantly reduced the germination and emergence parameters under evaluation. At water potentials of -0.65 and -0.9 MPa, seeds produced radicles and their germination capacity was high, since it was 95.0 and $82.2 \%$, respectively. Nevertheless, only few of them, and only at the highest temperature of germination, developed coleoptiles. In the case of the other plants, the radicles formed dried due to the lack of water. Therefore, the germination speed index of rye brome was very low under these conditions and it was on average, regardless of the temperature, 7.1 for a water potential of $-0.65 \mathrm{MPa}$ and 1.2 for a water potential of $-0.9 \mathrm{MPa}$. The substrate water potential also significantly affected the coleoptile and radicle length of seedlings as well as their above-ground fresh weight. The largest seedlings were observed in the substrate with distilled water. The particular aqueous polyethylene glycol solutions caused a significant deterioration in the parameters of rye brome seedlings (Table 4).

In the present experiment, air temperature was not found to have a significant effect on the germination capacity of rye brome (Table 1). However, this factor was shown to influence the speed of germination and emergence (Tables 2, 3). Significantly higher values of Maguire's index were found at a temperature of $25^{\circ} \mathrm{C}$ during the day and $22^{\circ} \mathrm{C}$ at night. Under these conditions, significantly higher emergence speed indices were demonstrated for all soil water potentials tested. In the case of the germination speed index, on the other hand, a decrease in temperature had a negative effect in the treatments with the three lowest water potentials, whereas it did not have a significant influence on this parameter in the control treatment and at a water potential of $-0.2 \mathrm{MPa}$. A decrease in temperature by $7^{\circ} \mathrm{C}$ during the day and by $8^{\circ} \mathrm{C}$ at night negatively affected the biometric characters and biomass of 
Bromus secalinus seedlings. Under these conditions, rye brome produced coleoptiles shorter by $34 \%$, in which the average biomass was lower by $25 \%$, and radicles shorter by $48 \%$ (Table 4 ).

In the other experiment, the substrate water potential was also shown to have a significant effect on the process of germination and emergence of Bromus secalinus. The highest germination capacity $(95.3 \%)$ and the fastest emergence were observed under the conditions of the highest soil moisture content $(-0.02$ MPa) (Tables 5, 6). At a water potential of $-0.07 \mathrm{MPa}$, only $7.5 \%$ less seeds germinated, but Maguire's emergence speed index under these conditions was significantly lower (9.5). A reduction in water potential down to the point of strong plant growth inhibition $(-0.16$ $\mathrm{MPa})$ resulted in a very low percentage of germinated seeds (15.0\%) and a low value of Maguire's index. At soil water potentials of -0.49 and $-1.55 \mathrm{MPa}$, Bromus secalinus seeds did not germinate. The delayed emergence had a negative effect on the biometric characters and biomass of rye brome seedlings. The length and weight of the coleoptile and radicle decreased with a reduction in soil moisture content (Table 7).
Temperature and air humidity also significantly affected the germination and emergence of rye brome (Tables 5,6). The germination capacity and emergence speed were significantly higher at a higher temperature and higher air humidity. A beneficial effect of higher temperature, which was $22^{\circ} \mathrm{C}$ during the day and $10^{\circ} \mathrm{C}$ at night, on the speed of emergence was observed in the case of all soil water potentials under evaluation. At an air humidity of $85-95 \%$, a higher emergence speed of rye brome was found for water potentials of -0.07 and $-0.16 \mathrm{MPa}$, whereas seeds that germinated at lower air humidity were marked by the fastest emergence under the most favourable water conditions (-0.02 MPa). The experiment revealed that rye brome seedlings were characterized by significantly better parameters at a higher temperature and air humidity (Table 7). At a temperature of $22 / 10^{\circ} \mathrm{C}$, compared to a lower temperature, rye brome produced, on average, $16.3 \mathrm{~mm}$ longer coleoptiles and $8.7 \mathrm{~mm}$ longer radicles. Air humidity determined the parameters of rye brome seedlings to a lesser extent. At an air humidity of 85-95\%, seedlings were characterized by a $5.7 \mathrm{~mm}$ longer coleoptile and a $10.1 \mathrm{~mm}$ longer radicle.

Table 1

Germination capacity (\%) of Bromus secalinus seeds depending on substrate water potential and air temperature

\begin{tabular}{|c|c|c|c|c|c|c|}
\hline \multirow{2}{*}{$\begin{array}{c}\text { Temperature } \\
\left({ }^{\circ} \mathrm{C}\right)\end{array}$} & \multicolumn{5}{|c|}{ Substrate water potential (MPa) } & \multirow{2}{*}{ Mean } \\
\hline & 0.0 & -0.2 & -0.4 & -0.65 & -0.9 & \\
\hline \multicolumn{7}{|c|}{ Actual data } \\
\hline $25 / 22$ & 96.0 & 93.7 & 96.0 & 93.3 & 89.7 & 93.7 \\
\hline $18 / 14$ & 98.7 & 98.3 & 97.7 & 96.7 & 74.7 & 93.2 \\
\hline Mean & 97.4 & 96.0 & 96.9 & 95.0 & 82.2 & - \\
\hline \multicolumn{7}{|c|}{ Transformed data } \\
\hline $25 / 22$ & 2.98 & 2.96 & 2.98 & 2.96 & 2.94 & 2.96 \\
\hline $18 / 14$ & 2.99 & 2.99 & 2.98 & 2.98 & 2.85 & 2.96 \\
\hline Mean & 2.99 & 2.98 & 2.98 & 2.97 & 2.90 & \\
\hline \multirow[t]{3}{*}{$\operatorname{LSD}_{(0.05)}$} & \multicolumn{5}{|c|}{ between substrate water potentials } & 0.01 \\
\hline & \multicolumn{5}{|c|}{ between temperatures } & n.s. \\
\hline & \multicolumn{5}{|c|}{ for the interaction: substrate water potential $\mathrm{x}$ temperature } & 0.04 \\
\hline
\end{tabular}

Table 2

Germination speed index of Bromus secalinus seeds (according to Maguire) depending on substrate water potential and air temperature

\begin{tabular}{cllllll}
\hline \multirow{2}{*}{$\begin{array}{c}\text { Temperature } \\
\left({ }^{\circ} \mathrm{C}\right)\end{array}$} & \multicolumn{5}{c}{ Substrate water potential (MPa) } & Mean \\
\cline { 2 - 5 } & 0.0 & -0.2 & -0.4 & -0.65 & -0.9 & 44.5 \\
\hline $25 / 22$ & 55.3 & 49.2 & 45.2 & 40.5 & 32.2 & 38.5 \\
$18 / 14$ & 56.9 & 51.3 & 39.6 & 30.3 & 14.2 & - \\
Mean & 56.1 & 50.3 & 42.4 & 35.4 & 23.2 & 2.3 \\
\hline $\mathrm{LSD}_{(0.05)}$ & between substrate water potentials & & 1.0 \\
& between temperatures & & 3.8 \\
\hline
\end{tabular}



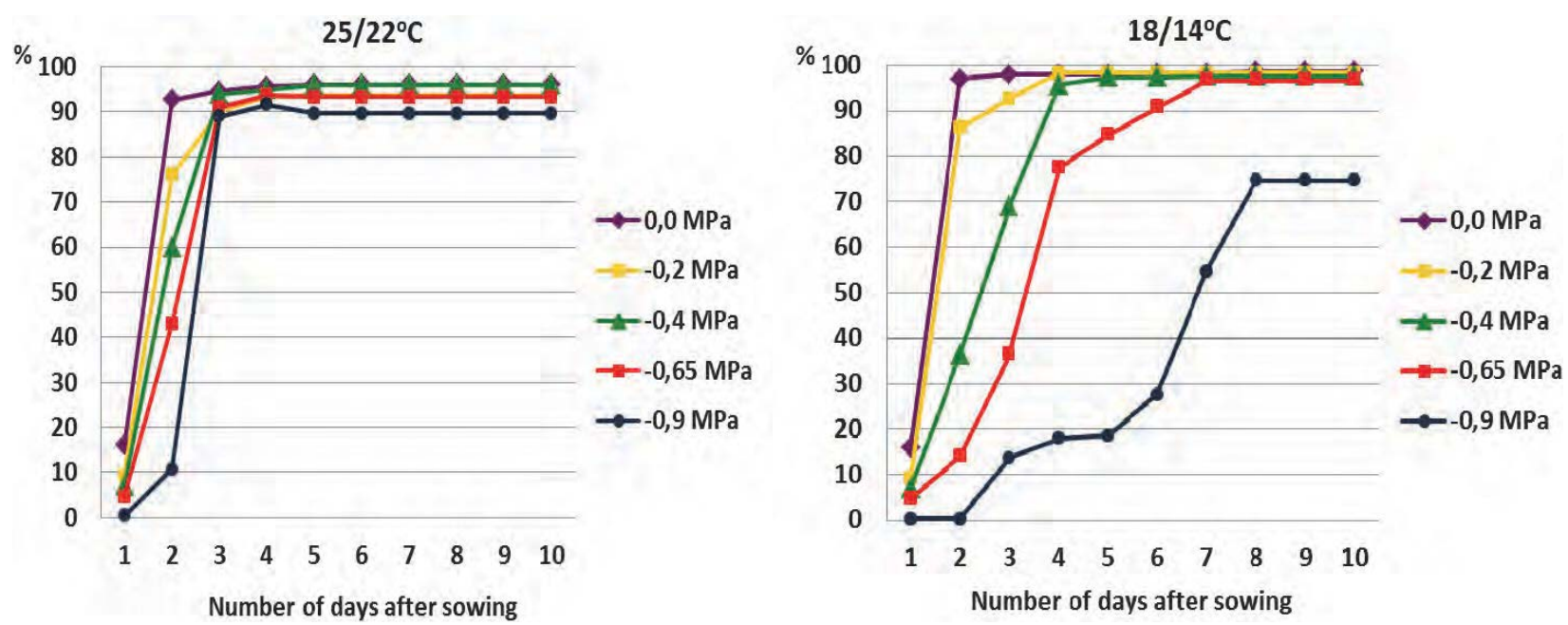

Fig. 1. Germination dynamics of Bromus secalinus seeds under water stress conditions

Table 3

Bromus secalinus emergence speed index (according to Maguire) depending on substrate water potential and air temperature

\begin{tabular}{ccccccc}
\hline \multirow{2}{*}{$\begin{array}{c}\text { Temperature } \\
\left({ }^{\circ} \mathrm{C}\right)\end{array}$} & 0.0 & -0.2 & -0.4 & -0.65 & Mean \\
\cline { 2 - 6 } & 27.4 & 24.5 & 21.5 & 14.1 & 2.3 & 18.0 \\
\hline $25 / 22$ & 23.0 & 18.1 & 7.2 & 0.0 & 0.0 & 9.7 \\
$18 / 14$ & 25.2 & 21.3 & 14.4 & 7.1 & 1.2 & - \\
Mean & between substrate water potentials & & 1.7 \\
\hline LSD $_{(0.05)}$ & between temperatures & & 0.8 \\
& for the interaction: substrate water potential x temperature & & 2.9 \\
\hline
\end{tabular}

Table 4

Coleoptile and radicle length as well as the fresh weight of a Bromus secalinus coleoptile depending on substrate water potential and air temperature

\begin{tabular}{lcccc}
\hline \multicolumn{2}{c}{ Experimental factors } & $\begin{array}{c}\text { Coleoptile length } \\
(\mathrm{mm})\end{array}$ & $\begin{array}{c}\text { Coleoptile fresh weight } \\
(\mathrm{mg})\end{array}$ & $\begin{array}{c}\text { Radicle length } \\
(\mathrm{mm})\end{array}$ \\
\hline & 0.0 & 61.2 & 15.4 & 106.2 \\
& -0.2 & 43.2 & 9.2 & 94.8 \\
Substrate water & -0.4 & 26.6 & 6.0 & 75.0 \\
potential $(\mathrm{MPa})$ & -0.65 & 9.3 & 2.0 & 32.8 \\
& -0.9 & 0.0 & 0.0 & 17.4 \\
& $\mathrm{LSD}_{(0.05)}$ & 5.6 & 1.1 & 6.8 \\
\hline & $25 / 22$ & 33.8 & 7.5 & 85.6 \\
Temperature $\left({ }^{\circ} \mathrm{C}\right)$ & $18 / 14$ & 22.3 & 5.6 & 44.9 \\
& $\operatorname{LSD}_{(0.05)}$ & 2.5 & 0.5 & 3.0 \\
\hline
\end{tabular}


Table 5

Germination capacity (\%) of Bromus secalinus seeds depending on soil water potential, air humidity and temperature

\begin{tabular}{|c|c|c|c|c|c|c|c|c|c|c|c|c|c|}
\hline \multirow{4}{*}{$\begin{array}{c}\text { Air } \\
\text { humidity }\end{array}$} & \multicolumn{10}{|c|}{ Soil water potential (MPa) } & \multirow{2}{*}{\multicolumn{2}{|c|}{$\begin{array}{l}\text { Mean for tem- } \\
\text { peratures }\end{array}$}} & \multirow{4}{*}{ Mean } \\
\hline & \multicolumn{2}{|c|}{-0.02} & \multicolumn{2}{|c|}{-0.07} & \multicolumn{2}{|c|}{-0.16} & \multicolumn{2}{|c|}{-0.49} & \multicolumn{2}{|c|}{-1.55} & & & \\
\hline & \multicolumn{12}{|c|}{ Temperature $\left({ }^{\circ} \mathrm{C}\right)$} & \\
\hline & $22 / 10$ & $16 / 5$ & $22 / 10$ & $16 / 5$ & $22 / 10$ & $16 / 5$ & $22 / 10$ & $16 / 5$ & $22 / 10$ & $16 / 5$ & $22 / 10$ & $16 / 5$ & \\
\hline \multicolumn{14}{|c|}{ Actual data } \\
\hline $85-95 \%$ & 97.7 & 95.3 & 92.7 & 85.3 & 53.3 & 4.3 & 4.0 & 0.0 & 0.0 & 0.0 & 49.5 & 37.0 & 43.3 \\
\hline $55-65 \%$ & 92.7 & 95.3 & 85.7 & 87.3 & 2.3 & 0.0 & 0.0 & 0.0 & 0.0 & 0.0 & 36.1 & 36.5 & 36.3 \\
\hline \multirow{2}{*}{ Mean } & 95.2 & 95.3 & 89.2 & 86.3 & 27.8 & 2.2 & 2.0 & 0.0 & 0.0 & 0.0 & 42.8 & 36.8 & \\
\hline & \multicolumn{2}{|c|}{95.3} & \multicolumn{2}{|c|}{87.8} & \multicolumn{2}{|c|}{15.0} & \multicolumn{2}{|c|}{1.0} & \multicolumn{2}{|c|}{0.0} & - & - & \\
\hline \multicolumn{14}{|c|}{ Transformed data } \\
\hline $85-95 \%$ & 2.99 & 2.97 & 2.96 & 2.92 & 2.68 & 1.06 & 0.93 & 0.00 & 0.00 & 0.00 & 1.91 & 1.39 & 1.65 \\
\hline $55-65 \%$ & 2.96 & 2.97 & 2.35 & 2.93 & 0.84 & 0.00 & 0.00 & 0.00 & 0.00 & 0.00 & 1.23 & 1.18 & 1.20 \\
\hline \multirow{2}{*}{ Mean } & 2.97 & 2.97 & 2.66 & 2.93 & 1.76 & 0.53 & 0.47 & 0.00 & 0.00 & 0.00 & 1.57 & 1.29 & \\
\hline & \multicolumn{2}{|c|}{2.97} & \multicolumn{2}{|c|}{2.79} & \multicolumn{2}{|c|}{1.15} & \multicolumn{2}{|c|}{0.23} & \multicolumn{2}{|c|}{0.00} & - & - & - \\
\hline \multirow[t]{6}{*}{$\operatorname{LSD}_{(0.05)}$} & \multicolumn{10}{|c|}{ between soil water potentials } & & & 0.41 \\
\hline & \multicolumn{10}{|c|}{ between temperatures } & & & 0.19 \\
\hline & \multicolumn{10}{|c|}{ between moisture contents } & & & 0.19 \\
\hline & \multicolumn{10}{|c|}{ for the interaction: soil water potential $\mathrm{x}$ temperature } & & & 0.69 \\
\hline & \multicolumn{10}{|c|}{ for the interaction: soil water potential $\mathrm{x}$ air humidity } & & & 0.69 \\
\hline & \multicolumn{10}{|c|}{ for the interaction: air humidity $\mathrm{x}$ temperature } & & & 0.35 \\
\hline
\end{tabular}

Table 6

Emergence speed index of Bromus secalinus seeds (according to Maguire) on soil water potential, air humidity and temperature

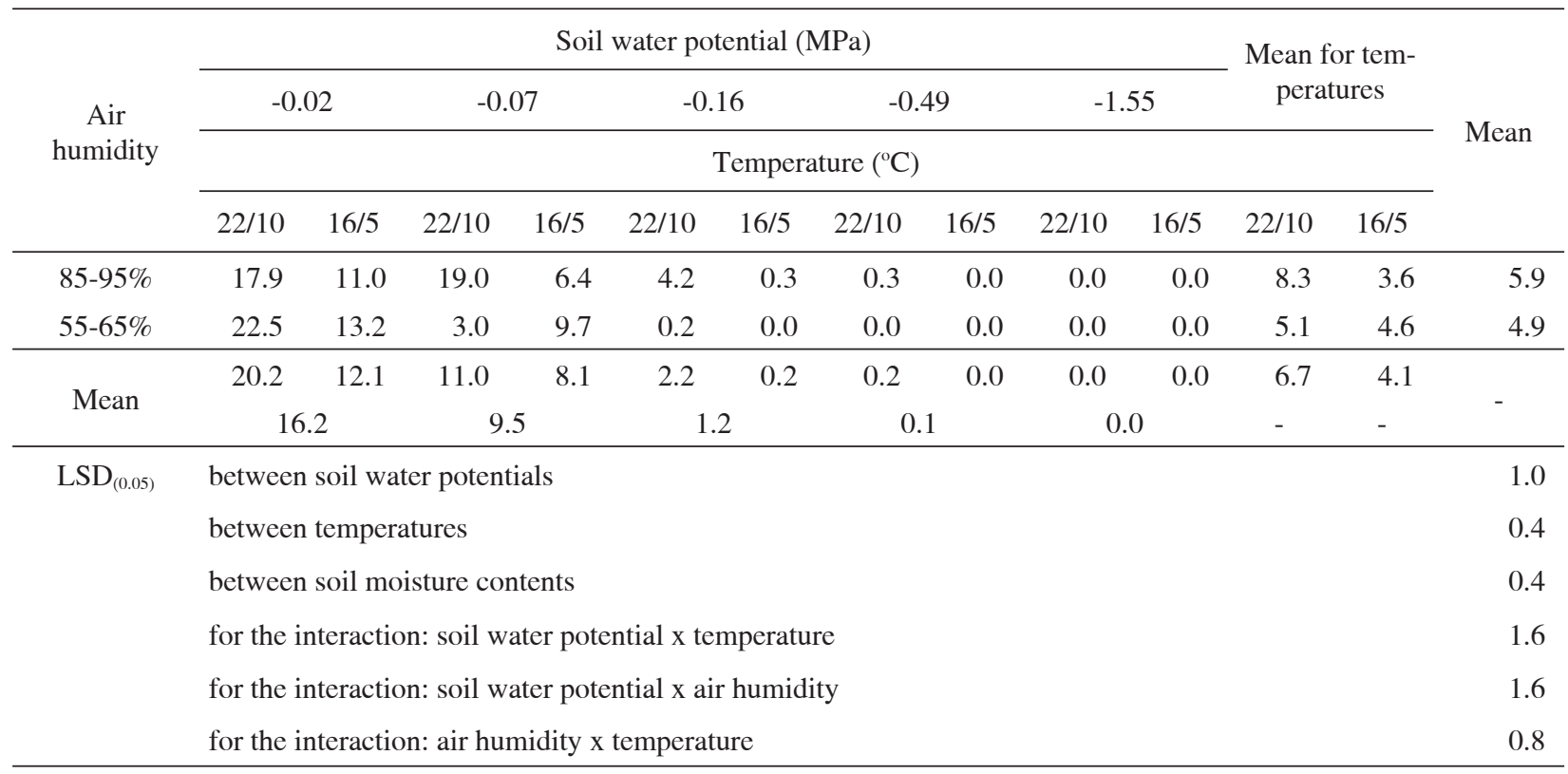


Table 7

Length of the Bromus secalinus coleoptile and radicle as well as their dry weight depending on soil water potential, air humidity, and temperature

\begin{tabular}{cccccc}
\hline Experimental factors & $\begin{array}{c}\text { Coleoptile length } \\
(\mathrm{mm})\end{array}$ & $\begin{array}{c}\text { Coleoptile dry weight } \\
(\mathrm{mg})\end{array}$ & $\begin{array}{c}\text { Radicle length } \\
(\mathrm{mm})\end{array}$ & $\begin{array}{c}\text { Radicle dry weight } \\
(\mathrm{mg})\end{array}$ \\
\hline \multirow{2}{*}{$\begin{array}{c}\text { Soil osmotic } \\
\text { potential }\end{array}$} & -0.02 & 74.0 & 2.35 & 96.9 & 1.36 \\
$(\mathrm{MPa})$ & -0.07 & 39.4 & 1.38 & 54.5 & 1.04 \\
& -0.16 & 2.9 & 0.04 & 8.1 & 0.15 \\
& -0.49 & 0.0 & 0.0 & 0.0 & 0.0 \\
& -1.55 & 0.0 & 0.0 & 0.0 & 0.0 \\
\hline \multirow{2}{*}{ Temperature } & $\mathrm{LSD}_{(0.05)}$ & 4.9 & 0.18 & 8.5 & 0.16 \\
$\left({ }^{\circ} \mathrm{C}\right)$ & $22 / 10$ & 46.9 & 1.49 & 57.5 & 1.01 \\
& $16 / 5$ & 30.6 & 1.04 & 48.8 & 0.69 \\
\hline & $\mathrm{LSD}_{(0.05)}$ & 3.3 & 0.12 & 5.6 & 0.11 \\
\hline Air humidity & $85-95 \%$ & 41.6 & 1.34 & 58.2 & 1.00 \\
$(\%)$ & $55-65 \%$ & 35.9 & 1.17 & 48.1 & 0.70 \\
& $\mathrm{LSD}_{(0.05)}$ & 3.3 & 0.12 & 5.6 & 0.11 \\
\hline
\end{tabular}

\section{DISCUSSION}

Germination and emergence are development stages that have an essential effect on further plant development. The proper process of these development stages gives a great chance for the fast growth of the plant and its high competitiveness against other surrounding vegetation. In most weed species, germination is dependent on specific environmental conditions or their interactions. Major factors that affect the germination process include the following: soil moisture content, light, temperature, soil $\mathrm{pH}$, oxygen, and seed dormancy period [11-15].

In the present experiment, the germination and emergence of Bromus secalinus were significantly dependent on soil water potential. In the experiment using polyethylene glycol aqueous solutions, brome was characterized by high germination capacity in all water potentials tested, whereas the emergence found in the control treatment as well as at water potentials of -0.2 and $-0.4 \mathrm{MPa}$ can be considered to be satisfactory. On the other hand, rye brome was marked by an even lower tolerance threshold in the soil substrate, since satisfactory emergence was found only at water potentials of -0.02 and $-0.07 \mathrm{MPa}$. The influence of the soil water content on plant emergence is also associated with soil crusting. The level of tolerance to soil water deficit in structural soils is higher than in soils with a medium or high level of crusting [12]. The studies of many researchers show that there is a strict relationship of soil moisture content, temperature and light conditions with the germination and emergence of species of the family Poaceae [16-18]. In the case of Bromus intermis, Grilz et al. [19] showed that this species germinated in a wide range of soil moisture conditions, but a germination capacity of above $50 \%$ was found in osmotic potentials of up to $-0.58 \mathrm{MPa}$. As regards other weeds, the level of substrate water potential that significantly decreased the germination was higher and it was as follows for the particular species: Themeda austrialis $-0.03 \mathrm{MPa}$, Danthonia sp. -0.06 MPa, Bothriochloa macra -0.07 MPa, and Stipa bigeniculata -0.09 MPa [12,20]. Among crop plants, soya bean, which has high water requirements during the initial growth stages, germinated properly only up to a water potential of $-0.4 \mathrm{MPa}$ [21].

Both experiments demonstrated a beneficial effect of higher air temperatures on the germination and emergence of Bromus secalinus. The studies of other researchers show that grass species of the genus Bromus germinate in a very wide range of temperatures. In the opinion of M e y e r et al. [22], such variation can be the beginning of genetic changes among a population, being an adaptive effect. K a c z m a r e k and Adamczewski [23] showed that a temperature range from $5 / 5^{\circ} \mathrm{C}$ to $20 / 30^{\circ} \mathrm{C}$ (day/night) did not have a significant effect on the germination capacity of Bromus sterilis, but it differentiated the speed of this process. Bromus arvensis and Bromus hordeaceus germinated in almost $100 \%$ under thermal conditions from $11 / 3^{\circ} \mathrm{C}$ to $25 / 17^{\circ} \mathrm{C}$, while at a temperature of $8 / 0^{\circ} \mathrm{C}$ (day/night) their germination capacity dropped to $80 \%$. Bromus sterilis and Bromus tectorum exhibited greater sensitivity to low temperatures, while the presence of light had an additional inhibitive effect on the germination process [24]. In his research, $\mathrm{H} \mathrm{i} 1$ t o $\mathrm{n}$ [25][25] also demonstrated the inhibitive effect of light 
on the germination of Bromus sterilis. Furthermore, he proved a temperature range from 13 to $23^{\circ} \mathrm{C}$ to be optimal thermal conditions for the germination of this species. According to Th i 11 et al. [16], Bromus tectorum was marked by a faster speed of emergence in constant temperatures than in variable temperatures. The papers of many authors show that germination and emergence that take place under optimal thermal conditions reduce the negative effect of adverse soil moisture conditions $[19,26]$.

\section{CONCLUSIONS}

1. The germination capacity of Bromus secalinus L. and the weight of sprouts produced were significantly dependent on the water potential in the aqueous polyethylene glycol solutions and on the soil water potential.

2. The germination and emergence speed indices of Bromus secalinus L. significantly decreased at lower substrate water potential and at a lower temperature.

3. A decrease in soil water potential below $-0.16 \mathrm{MPa}$ (the point of strong growth inhibition) completely inhibited the emergence of Bromus secalinus.

4. A reduction in temperature and air humidity negatively affected the emergence and biometric characters of rye brome seedlings.

\section{Acknowledgments}

The present research was funded by the Department of Herbology and Plant Cultivation Techniques, Department of Plant Physiology, University of Life Sciences in Lublin.

\section{Authors' contributions}

The following declarations about authors' contributions to the research have been made: design of experiments: $\mathrm{MH}, \mathrm{JK}, \mathrm{SM}$; performance of experiments: $\mathrm{MH}, \mathrm{SM}$; analysis of experimental data: $\mathrm{MH}$, $\mathrm{SM}$; writing of the paper: MH, JK, SM.

\section{REFERENCES}

1. Zarzycki K, Mirek Z. Red list of plants and fungi in Poland. Cracow: W. Szafer Institute of Botany, Polish Academy of Sciences. 2006.

2. Latowski K, Chmiel J, Jackowiak B, Żukowski W. Participation of anthropophytes in the segetal flora of Wielkopolska. Fragm Agron. 2010; 27: 103-111.

3. Kącki Z, Szcześniak E, Czarniecka M. Bromus secalinus (Poaceae) in Lower Silesia - occurrence and threats. Acta Bot Siles. 2011; 1 suppl: 66-68.
4. Korniak T, Dynowski P. Bromus secalinus (Poaceae) - a vanishing or a widespread weed species of cereal crops in north-eastern Poland? Fragm Flor Geobot Pol. 2011; 18: 341-348.

5. Kapeluszny J, Haliniarz M. Expansive and treatend segetal flora species in middle-eastern Poland. Ann UMCS Sec E. 2010; 65(1): 26-33. http://dx.doi.org/ 10.2478/v10081-010-0004-2

6. Rzymowska Z, Skrzyczyńska J, Skrajna T. Changes in occurrence of rare segetal species in the Landscape Park "Podlaski Przełom Bugu" after 10 years of studies. Pam Pul. 2006; 143: 145-155.

7. Rzymowska Z, Skrzyczyńska J, AffekSt arczewska A. Occurrence and some morphological features of Bromus secalinus L. in agrocenoses of the "Podlaski Przełom Bugu" mesoregion. Fragm Agron. 2010; 27: 102-110.

8. Skrajna T, Skrzyczyńska J, Rzymowska Z. Occurrence of Bromus secalinus L. in agrocenosis of the Kałuszyn Upland. Zesz Nauk AP Siedl Ser Rol. 2005; 66/67: 65-73.

9. Maguire JD. Speed of germination-aid in selection and evaluation for seedling emergence and vigor. Crop Sci. 1962; 2(2): 176. http://dx.doi.org/10.2135/cropsci1962. 0011183X000200020033x

10. Słowińska-Jurkiewicz A. Struktura i właściwości powietrzno-wodne gleb wytworzonych z lessu. Roczn Nauk Rol Ser D. 1989; 218: 76.

11. Peters NCB, Atkins HA, Brain P. Evidence of differences in seed dormancy among populations of Bromus sterilis. Weed Res. 2000; 40(5): 467-478. http://dx.doi.org/ 10.1046/j.1365-3180.2000.00202.x

12. B a sk in C C, B a sk in J M. Seeds: ecology, biogeography, and evolution of dormancy and germination. Elsevier. 2001.

13. Kapeluszny J, Haliniarz M. Selected elements of germination biology of flaxweed (Descurainia sophia Webb. ex Prantl.) and rye brome (Bromus secalinus L.). Ann UMCS Sec E. 2007; 62: 226-233.

14. S tokłos a A. Influence of light and temperature on germination of wild oat (Avena fatua $\mathrm{L}$.) varieties. Ann UMCS Sec E. 2007; 62: 56-69.

15. Kapeluszny J, Haliniarz M, Harasim P. The effect of soil environment on germination and emergence of prickly lettuce (Lactuca serriola L.). Acta Agrobot. 2011; 64(3): 103. http://dx.doi.org/10.5586/aa.2011.037

16. Thill DC, Schirman RD, Appleby AP. Influence of soil moisture, temperature and compaction on the germination and emergence of downy brome (Bromus tectorum). Weed Sci. 1979; 27: 625-630.

17. Colbach N, Chauvel B, Durr C, Richard G. Effect of environmental conditions on Alopecurus myosuroides germination. I. Effect of temperature and light. Weed Res. 2002; 42(3): 210-221. http://dx.doi.org/10.1046 /j.0043-1737.2002.00279.x

18. Colbach N, Durr C, Chauvel B, Richard G. Effect of environmental conditions on Alopecurus myosuroides 
germination. II. Effect of moisture conditions and storage length. Weed Res. 2002; 42(3): 222-230. http://dx.doi.org/ 10.1046/j.0043-1737.2002.00280.x

19. Grilz PL, Romo JT, Young JA. Comparative germination of smooth brome and plains rough fescue. PNAT. 1994; 26: 157-170.

20. Hag on M W, Chan CW. The effects of moisture stress on the germination of some Australian native grass seeds. Aust J Exp Agric. 1977; 17(84): 86-89. http://dx.doi.org/ 10.1071/EA9770086

21. Michałek S, Borowski E. Seed germination and seedling growth of the Polish soybean [Glycine max (L.) Merr.] cultivars in drought conditions. Biul IHAR. 2002; 223/224: 195-201.

22. Meyer SE, Allen PS, Beckstead J.Seedgermination regulation in Bromus tectorum (Poaceae) and its ecological significance. Oikos. 1997; 78(3): 475. http://dx.doi.org/ $10.2307 / 3545609$

23. Kaczmarek S, Ad a mczewski K. Bromus sterilis - expansive weed, germination and weed thresholds. Ann UMCS Sec E. 2007; 62: 17-22.

24. Andersson L, Milberg P, Schutz W, Steinmetz O. Germination characteristics and emergence time of annual Bromus species of differing weediness in Sweden. Weed Res. 2002; 42(2): 135-147. http://dx.doi.org/10. 1046/j.1365-3180.2002.00269.x

25. Hilton JR. The influence of temperature and moisture status on the photoinhibition of seed germination Bromus sterilis L. by the far-red absorbing form of phytochrome. New Phytol. 1984; 97(3): 369-374. http://dx.doi.org/10. 1111/j.1469-8137.1984.tb03602.x

26. McGinnies W J. Effects of moisture stress and temperature on germination of six range grasses. Agron J. 1960; 52(3): 159. http://dx.doi.org/10.2134/agronj1960.00021962 005200030012xhes hf

\section{Kiełkowanie ziarniaków stokłosy żytniej (Bromus secalinus L.) w symulowanej suszy i zróżnicowanych warunkach termicznych}

\section{Streszczenie}

Celem badań było porównanie kiełkowania ziarniaków stokłosy żytniej (Bromus secalinus L.) i początkowego wzrostu siewek w warunkach symulowanej suszy i zróżnicowanych warunkach termicznych.

Badania obejmowały dwa doświadczenia przeprowadzone $\mathrm{w}$ warunkach laboratoryjnych wiosną 2012 roku. Pierwszy eksperyment polegał na ocenie dynamiki kiełkowania oraz cech biometrycznych i masy siewek w roztworach polietylenoglikolu (PEG 8000), w których potencjał wodny wynosił: $-0,2 ;-0,4 ;-0,65$; $-0,9 \mathrm{MPa}$ oraz wody destylowanej jako kontroli. Doświadczenie przeprowadzono w temperaturach: $25 / 22^{\circ} \mathrm{C}$ oraz $18 / 14^{\circ} \mathrm{C}$ dzień/noc, przy względnej wilgotności powietrza $90 \%$. Drugi eksperyment z użyciem gleby płowej wytworzonej z lessu, jako podłoża do kiełkowania, przeprowadzono w komorze wegetacyjnej w dwóch poziomach wilgotności (55-65\% i 85-95\%) i temperatury powietrza $\left(22 / 10^{\circ} \mathrm{C}\right.$ i $\left.16 / 5^{\circ} \mathrm{C}\right)$. Wilgotność gleby ustalono metodą wagową, a odpowiadający jej potencjał wodny wynosit: $-0,02,-0,07,-0,16,-0,49,-1,55 \mathrm{MPa}$.

Zdolność kiełkowania, wchody oraz wytworzona masa kiełków Bromus secalinus zależały istotnie od potencjału wodnego w roztworu polietylenoglikolu i potencjału wodnego gleby. Wschody Bromus secalinus całkowicie zahamowało zmniejszenie potencjału wodnego gleby poniżej -0,16 MPa (punkt silnego hamowania wzrostu). Wschody i cechy biometryczne siewek stokłosy żytniej zależały istotnie od temperatury i wilgotności powietrza.

Handling Editor: Elżbieta Weryszko-Chmielewska

This is an Open Access digital version of the article distributed under the terms of the Creative Commons Attribution 3.0 License (creativecommons.org/licenses/by/3.0/), which permits redistribution, commercial and non-commercial, provided that the article is properly cited.

(CThe Author(s) 2013 Published by Polish Botanical Society 